\title{
Stable isotope ratios in alpine rock ptarmigan and black grouse sampled along a precipitation gradient
}

\author{
Nina Dehnhard ${ }^{\mathrm{a}, *}$, Elizabeth Yohannes ${ }^{\mathrm{b}}$, Hannes Jenny ${ }^{\mathrm{c}}$, Gernot Segelbacher $^{\mathrm{d}}$ \\ ${ }^{a}$ University of Antwerp, Department Biology - Behavioural Ecology \& Ecophysiology Group, Campus Drie Eiken, \\ Universiteitsplein 1, 2610 Antwerp (Wilrijk), Belgium \\ ${ }^{\mathrm{b}}$ University of Konstanz, Limnological Institute, Mainaustrasse 252, 78457 Konstanz, Germany \\ ${ }^{\mathrm{c}}$ Department of Wildlife and Fishery Service Grison, Loëstrasse 14, 7001 Chur, Switzerland \\ ${ }^{\mathrm{d}}$ Wildlife Ecology \& Management, University of Freiburg, Tennenbacher Str. 4, 79106 Freiburg, Germany
}

\begin{abstract}
Rock ptarmigan (Lagopus muta) and black grouse (Tetrao tetrix) are two closely related alpine bird species that form relict populations in the European Alps. Besides manifold anthropogenic influences in this region, global climate change is forecast to lead to significant changes in temperatures and precipitation. We here analysed stable isotope ratios $\left(\delta^{13} \mathrm{C}\right.$ and $\left.\delta^{15} \mathrm{~N}\right)$ of feathers of both bird species and their potential dietary plants across a longitudinal precipitation gradient in south-east Switzerland.

Plant $\delta^{13} \mathrm{C}$ was higher at higher altitudes and in drier areas (coinciding with higher longitudes) while plant $\delta^{15} \mathrm{~N}$ did not differ geographically. Black grouse $\delta^{13} \mathrm{C}$ reflected the longitudinal pattern in precipitation and plant $\delta^{13} \mathrm{C}$, and there was no indication for a change in dietary composition with precipitation (i.e. no significant changes in $\delta^{15} \mathrm{~N}$ ). In contrast, rock ptarmigan $\delta^{13} \mathrm{C}$ was independent of precipitation and plant $\delta^{13} \mathrm{C}$ values and showed a significant increase in $\delta^{15} \mathrm{~N}$ towards drier areas, suggesting a potential dietary shift.

In rock ptarmigan, we furthermore investigated intraspecific differences with age, between males and females and among years, and did not find any biologically meaningful intraspecific differences. Interspecifically, rock ptarmigan feathers had significantly higher $\delta^{13} \mathrm{C}$ and lower $\delta^{15} \mathrm{~N}$ values than black grouse, reflecting a dietary segregation between both species. This may partly be due to the higher altitudinal distribution of rock ptarmigan in combination with an altitudinal gradient in plant $\delta^{13} \mathrm{C}$. In addition, however, species also segregated in $\delta^{15} \mathrm{~N}$, most likely caused by a higher proportion of invertebrate diet in black grouse.
\end{abstract}

\section{Zusammenfassung}

Alpenschneehuhn (Lagopus muta) und Birkhuhn (Tetrao tetrix) sind zwei nahe verwandte Vogelarten, die Reliktpopulationen in den Europäischen Alpen bilden. Neben vielfältigen anthropogenen Einflüssen in dieser Region werden wegen des globalen Klimawandels signifikante Veränderungen in Temperatur und Niederschlag erwartet. Wir analysierten die stabile Isotopenzusammensetzung $\left(\delta^{13} \mathrm{C}\right.$ und $\left.\delta^{15} \mathrm{~N}\right)$ von Federn sowie potentiellen Nahrungspflanzen entlang eines Niederschlagsgradienten im Südosten der Schweiz.

\footnotetext{
*Corresponding author. Tel.: +320326523 47; fax: +320382022 71

E-mail address: nina.dehnhard@uantwerpen.be (N. Dehnhard).
} 
Die $\delta^{13} \mathrm{C}$-Werte der Nahrungspflanzen nahmen mit Trockenheit (übereinstimmend mit zunehmenden Längengraden) und Höhe zu, während die Geographie keine Auswirkungen auf die $\delta^{15} \mathrm{~N}$-Werte der Nahrungspflanzen hatte. $\delta^{13} \mathrm{C}$-Werte von Birkhuhnfedern reflektierten den longitudinalen Gradienten in Niederschlag und Pflanzen- $\delta^{13} \mathrm{C}-$ Werten, und es gab keine Anzeichen für eine Änderung der Nahrungszusammensetzung entlang des Niederschlagsgradienten (d.h. keine signifikanten Veränderungen in $\delta^{15} \mathrm{~N}$ ). In Alpenschneehuhnfedern hingegen waren die $\delta^{13} \mathrm{C}$-Werte unabhängig von Niederschlag und Pflanzen- $\delta{ }^{13} \mathrm{C}$-Werten. Die $\delta^{15} \mathrm{~N}$-Werte in Alpenschneehuhnfedern nahmen zudem signifikant mit Trockenheit zu, was potentiell auf eine Veränderung der Nahrungszusammensetzung entlang des Niederschlagsgradienten hinweist.

An Alpenschneehühnern untersuchten wir auch intraspezifische Unterschiede zwischen Altersklassen, Männchen und Weibchen sowie verschiedenen Jahren, fanden jedoch keine biologisch aussagekräftigen intraspezifischen Unterschiede. Interspezifisch wiesen Alpenschneehuhnfedern signifikant höhere $\delta^{13} \mathrm{C}$ und niedrigere $\delta^{15} \mathrm{~N}$-Werte auf als Birkhühner, was eine Abgrenzung der beiden Arten in ihrer Nahrung reflektiert. Dies kann zum Teil durch die unterschiedliche Nutzung des Lebensraums in Kombination mit dem Gradienten in Pflanzen- $\delta{ }^{13} \mathrm{C}$ mit ansteigender Höhe erklärt werden. Alpenschneehühner erschließen auch hochalpine Regionen, während Birkhühner nahe der Baumgrenze verbleiben. Zusätzlich unterschieden sich beide Arten jedoch auch in ihren $\delta^{15} \mathrm{~N}$-Werten, was vermutlich durch einen höheren Anteil von Invertebraten in der Nahrung von Birkhühnern verursacht wird.

Keywords: European Alps; Global climate change; Plant isotope; Precipitation; Stable isotope analysis

\section{Introduction}

As typical for mountainous areas, the European Alps show a high diversity of different climate zones on a relatively small scale, mainly driven by the continuous temperature decrease with elevation (Frey \& Lösch 2004). In addition, the European Alps form a barrier against weather fronts, which leads to higher precipitation at the edges and drier conditions in the central areas (Frey \& Lösch 2004). As temperature and moisture are important determinants of the ecological niche of plants and animals (Begon, Townsend, \& Harper, 2006), this diversity in Alpine climate habitats is also reflected in the diversity of habitats and species. This richness in Alpine wildlife is, however, severely affected by anthropogenic influences, such as the use of pastures and changes in grazing regimes (Meusburger \& Alewell 2008; Patthey, Signorell, Rotelli, \& Arlettaz, 2012; Paschetta et al., 2013), installation of hydroelectric power plants (Truffer, Markard, Bratrich, \& Wehrli, 2001; Fette, Weber, Peter, \& Wehrli, 2007), or recreational snow sport activities (Braunisch, Patthey, \& Arlettaz, 2010; Negro, Isaia, Palestrini, Schoenhofer, \& Rolando, 2010). In addition, the European Alps are one of the areas with the strongest observed warming trend worldwide, regionally showing increases of $1-2{ }^{\circ} \mathrm{C}$ of average annual air temperature during the 20th century (Begert, Schlegel, \& Kirchhofer, 2005; Parolo \& Rossi 2008). Along with further temperature increases, climate models for the European Alps predict changes in precipitation patterns, with generally drier summers and wetter winters (including rain), and an increase of extreme weather events including extreme rainfalls but also temporal droughts (Zimmermann, Gebetsroither, Züger, Schmatz, \& Psomas, 2013; Gobiet et al., 2014). These climatological effects will lead to an elevation of the tree line, which is partly already visible (Dullinger, Dirnböck, \& Grabherr,
2004). In addition to land use changes we will likely observe a reduction in size of high-alpine meadow habitats that goes along with an overall biodiversity loss (Dirnböck, Dullinger, \& Grabherr, 2003; Engler et al., 2011).

Many of the now threatened high-altitude species are relict species that have survived in mountainous areas since the last glacial period, boosting local biodiversity (Ohlemüller et al., 2008; Dirnböck, Essl, \& Rabitsch, 2011). Two prominent and closely related species that form relict populations in the European Alps are rock ptarmigan (Lagopus muta) and black grouse (Lyrurus tetrix). Rock ptarmigan are found in rocky areas above the tree line (from about $1800 \mathrm{~m}$ and up to more than 3000 m) (Glutz von Blotzheim, Bauer, \& Bezzel, 1973; Pernollet, Korner-Nievergelt, \& Jenni, 2015). In contrast, black grouse show a boreal distribution, with the main alpine habitat being the upper forest edge, i.e. the area of the tree line (Glutz von Blotzheim et al. 1973). Populations of both species in the European Alps were considered as stable until the mid-1990s (Schmid, Luder, Naef-Daenzer, Graf, \& Zbinden, 1998; Peronace, Cecere, Gustin, \& Rondinini, 2012). However, in the following decade rock ptarmigan declined by about 30\% in both Switzerland (Keller, Gerber, Schmid, Volet, \& Zbinden, 2010) and Italy (Peronace et al. 2012). In the same period, black grouse numbers declined by up to $20 \%$ in Italy (Peronace et al. 2012). Whether these declining trends that also persist on a global scale (Storch 2007) are already caused by the effects of climate change, or potentially other anthropogenic influences, is unknown and analyses are aggravated by the fact that population declines vary in size among regions (Furrer et al. 2016). However, with ongoing climate change effects, both rock ptarmigan and black grouse will have to track the shift of the tree line to higher elevations, a trend that is already visible in rock ptarmigan (Pernollet et al. 2015). Especially under warming 
scenarios exceeding $2{ }^{\circ} \mathrm{C}$, both species will furthermore suffer from a loss in suitable habitat (Revermann, Schmid, Zbinden, Spaar, \& Schroder, 2012; Zurell et al., 2012).

Both rock ptarmigan and black grouse feed predominantly on plants, especially on leafs and buds of heather (Ericacea), including bilberry (Vaccinium myrtillus), mountain cranberry (Vaccinium vitis-idaea) and black crowberry (Empetrum nigrum) as well as dwarf willows (Salix herbacea, Salix retusa) and - especially young chicks - also on insects (Glutz von Blotzheim et al. 1973; Lieser, Zakrzewski, \& Sittler, 1997; Bertermann, Weber-Sparenberg, Pechura, Renard, \& Bergmann, 1998; Starling-Westerberg 2001; Beeston, Baines, \& Richardson, 2005). Habitat suitability models for the presence of both species in the European Alps generally reflect the importance of patchy and heterogeneous habitat structures for food and shelter (Favaron, Scherini, Preatoni, Tosi, \& Wauters, 2006; Zohmann \& Wöss 2008; Patthey et al. 2012). Schweiger, Nopp-Mayr, \& Zohmann (2012) furthermore highlighted the importance of dwarf shrubs for both species, and ant hills (reflecting an insect food source) for black grouse. While current diet and habitat characteristics appear to be well known, it remains open how the predicted changes in temperature, precipitation, reduced (and higher elevated) suitable habitat and changed plant composition will affect diet and in the long term population trajectories.

As a first step we here aim to infer how precipitation patterns may affect summer diet, by comparing dietary changes along a distinct gradient in precipitation within the Swiss canton of Grisons (Frei \& Schär 1998; see Fig. 1). Stable isotopes, particularly the combination of $\delta^{15} \mathrm{~N}$ and $\delta^{13} \mathrm{C}$ isotope ratios provide a comprehensive picture of dietary relationships: $\delta^{15} \mathrm{~N}$ increases with each trophic level and can therefore be used to assess the trophic position in the food web (reviewed in Caut, Angulo, \& Courchamp, 2009). In contrast, $\delta^{13} \mathrm{C}$ varies with bed-rock and between C3 and C4-plants (Fry 2006). Furthermore, $\delta^{13} \mathrm{C}$ ratios in plants decrease with rainfall (Stewart, Turnbull, Schmidt, \& Erskine, 1995; Ferrio \& Voltas 2005) and increase with elevation (Körner, Farquhar, \& Roksandic, 1988; Van de Water, Leavitt, \& Betancourt, 2002). Feathers are a frequently analysed tissue and reflect the diet during, or shortly prior to moult, as they remain metabolically inert after their formation and even after death (Bearhop, Waldron, Votier, \& Furness, 2002). Black grouse moult their entire plumage, and rock ptarmigan their primary and secondary wing feathers during the summer months, towards the end of the chick rearing period (Glutz von Blotzheim et al. 1973). The feather samples analysed in this study therefore reflect the diet during summer.

By analysing precipitation patterns, plant and feather isotopes, we thus aimed to (1) investigate potential differences in isotopic composition and consequently diet related to regional precipitation patterns. Based on the literature, we expected plant $\delta^{13} \mathrm{C}$ and consequently feather $\delta^{13} \mathrm{C}$ to increase along the precipitation gradient with longitude, but expected no changes in plant and feather $\delta^{13} \mathrm{C}$ with latitude.
We furthermore expected generally higher $\delta^{13} \mathrm{C}$ values in plant samples at higher altitudes and consequently in feathers of rock ptarmigan compared to black grouse.

Plant $\delta^{15} \mathrm{~N}$ values should not be affected by precipitation, and we therefore expected no gradient in plant $\delta^{15} \mathrm{~N}$ with longitude or altitude. We had no specific expectations as to how precipitation would affect dietary composition of rock ptarmigan and black grouse. However, if precipitation would affect the food choice of either of the species, we expected to see a change in $\delta^{15} \mathrm{~N}$ with longitude.

We further investigated (2) intra-specific dietary differences between adult and immature birds and between adult males and females in rock ptarmigan. As juveniles have been described to feed on a more insect-rich diet, we expected to find higher $\delta^{15} \mathrm{~N}$ values in feathers of immatures (i.e. the first set of primaries and secondaries that is built when still guarded by the hens) compared to adults (moulted in summer at the same time as chick rearing). Finally (3), we tested whether rock ptarmigan and black grouse differ in their diet. Due to the differences in altitudinal distribution during summer, we expected to find higher $\delta^{13} \mathrm{C}$ values in rock ptarmigan than black grouse. Assuming a similar diet in both species, we however expected similar $\delta^{15} \mathrm{~N}$ values in both species.

\section{Materials and methods}

\section{Collection of feathers}

Feathers of black grouse and rock ptarmigan were obtained from several hunting districts within Grisons (Fig. 1), during the hunting season between mid-October to end of November. Hunters were obliged to deliver feather samples from shot black grouse (secondary wing feathers or body coverts; in 2005-2007), and rock ptarmigan (secondary wing feathers; in 2008-2012) to the Department of Wildlife and Fishery Service Grison. Feathers were stored in plastic bags along with information about age and sex (identified from plumage characteristics). For black grouse, the detailed coordinates of the shot locations were also registered, whereas for rock ptarmigan only the municipality was noted. For subsequent analyses regarding locations, we therefore used the principle town/village within the municipality for rock ptarmigan, but the detailed location for black grouse.

Feathers from black grouse were solely from male birds, either adult or immature. Feathers from rock ptarmigan were from both sexes and included both adults and immatures. In few cases $(N=11$ out of 190 feather samples in total), sex or age was not noted, and sample sizes therefore vary slightly among analyses. In order to understand potential intra-specific variation in stable isotope ratios across years, between sexes, and age (adults and immatures), we chose the municipality with the highest number of shot animals (Pontresina; see location in Fig. 1) and analysed a total of 78 samples from rock ptarmigan, equally covering both sexes and age groups from the years 2008 to 2012. To analyse 


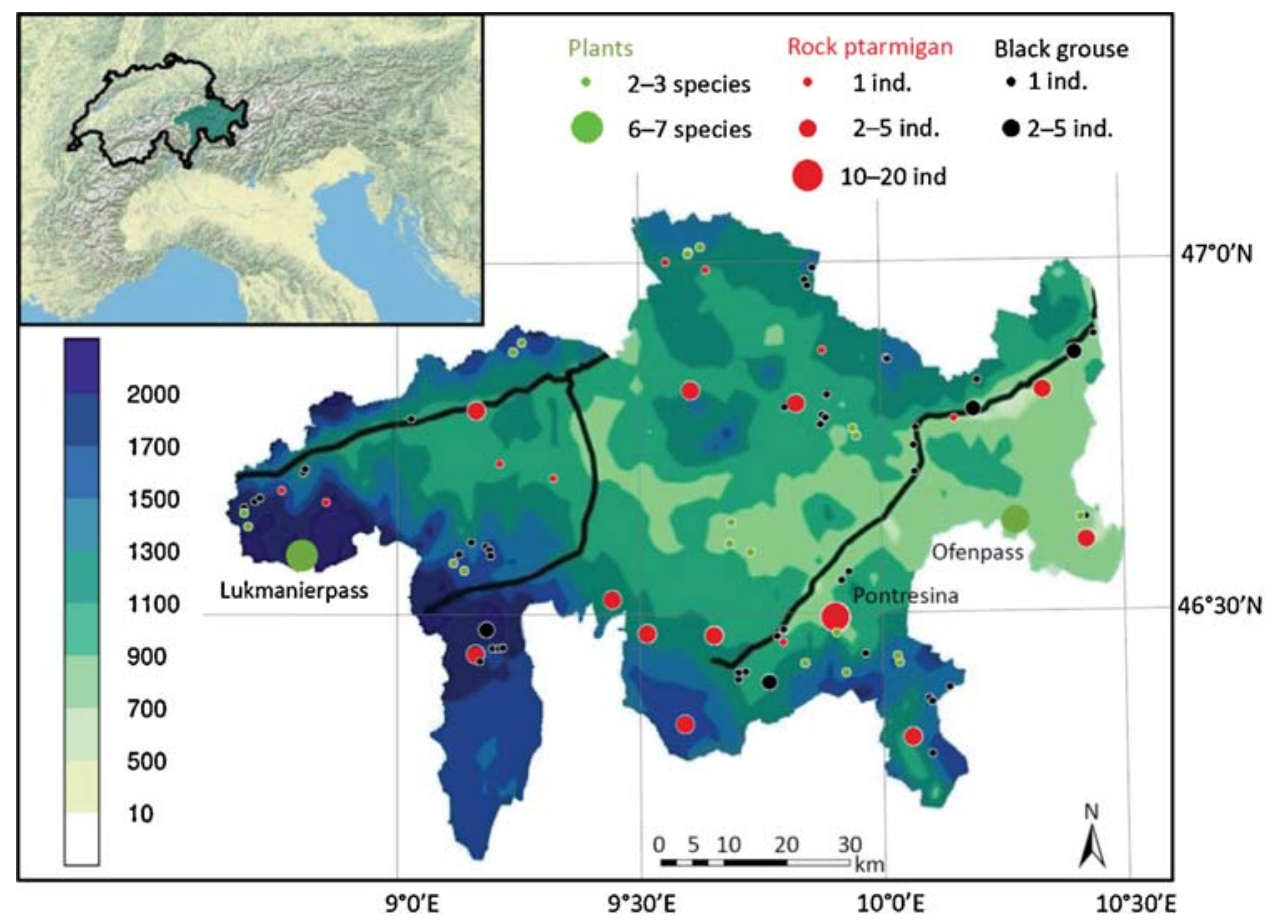

Fig. 1. Location of Switzerland (black frame) and Grisons (blue-green coloured) within the European Alps (inserted plot in top-left corner). The main figure shows the sum of precipitation (in mm; see legend on the left hand side) in the year 2013 in Grisons and sample locations of plants (green), rock ptarmigan (red) and black grouse (black) feathers. For the two grouse species the size of the dots reflects the number of sampled individuals in the year 2005 (black grouse) and 2009 (rock ptarmigan, respectively). Lukmanierpass and Ofenpass (marked with large green dots) are the locations where plants were sampled more intensively to compare interspecific isotopic variation. Pontresina, the location where most rock ptarmigan were shot, is highlighted as samples from this location were used for inter-annual and intra-specific comparisons of isotope ratios. A total of $N=137$ feather samples of rock ptarmigan, $N=53$ feather samples of black grouse and $N=197$ plant samples were analysed. Sum of precipitation as shown here is based on spatial interpolation of weather station data (according to RhiresY v.1.0.; details in Frei et al. 1998). The background map was modified based on a figure provided by MeteoSwiss. (For interpretation of the references to color in this figure legend, the reader is referred to the web version of this article.)

the geographic effects and species differences, black grouse feathers from $2005(N=53$ samples $)$ and rock ptarmigan feathers from 2009 ( $N=59$ samples) from across Grisons $(N=19$ and 21 municipalities for black grouse and rock ptarmigan, respectively) were analysed (Fig. 1).

\section{Collection of plant samples}

Plants were sampled between 10th of July and 23rd of August 2013. Sampling locations were distributed across Grisons matching the overall hunting locations of the birds (Fig. 1). Per location (e.g. Vilan), we collected plant samples at one to two different plots, if possible at different elevations (e.g. one at $1900 \mathrm{~m}$, and one at $2300 \mathrm{~m}$; see Table A1 for details about sampled plant species per location). At each plot, we collected 3-5 samples per plant species, and ideally from at least two species (depending on availability at the plot), generally one from the family Ericacea (mostly bilberry, Vaccinium myrtillus) and the second either from Salicacea (Salix reticulata) or Roseacea (Geum montanum or Dryas octopetala). Each sample consisted of one branch with several leaves, and samples were collected from separate specimens that grew at least $3 \mathrm{~m}$ apart from each other.
In order to estimate the isotopic variation among plant species also within the plant family Ericacea, we covered two locations (Ofenpass and Lukmanierpass; see Fig. 1) more closely and analysed samples from 6 and 7 species, respectively.

\section{Stable isotope analyses}

Plant samples were dried in a drying oven at $50{ }^{\circ} \mathrm{C}$ for at least $48 \mathrm{~h}$. We ground two leaves per individual plant and mixed them thoroughly. Sub-samples (ca. $0.5 \mathrm{mg}$ ) were weighed into $0.3 \mathrm{~mm} \times 0.5 \mathrm{~mm}$ tin capsules to the nearest $0.001 \mathrm{mg}$, using a micro-analytical balance.

For feather samples, we used the distal end of feathers. Only feathers free of visible contamination (dirt or blood) were used. Feathers were rinsed with $75 \%$ ethanol and subsequently with distilled water, and then dried in a drying oven at $50{ }^{\circ} \mathrm{C}$ for at least $24 \mathrm{~h}$. Sub-samples of $0.8-0.9 \mathrm{mg}$ were weighed into tin capsules.

Samples were combusted in a Pyrocube elemental analyser. The resulting $\mathrm{CO}_{2}$ and $\mathrm{N}_{2}$ were separated by gas chromatography and admitted into the inlet of a Micromass 
(Manchester, UK) Isoprime isotope ratio mass spectrometer (IRMS) for determination of ${ }^{13} \mathrm{C} /{ }^{12} \mathrm{C}$ and ${ }^{15} \mathrm{~N} /{ }^{14} \mathrm{~N}$ ratios. Measurements are reported in $\delta$-notation $\left(\delta^{13} \mathrm{C}\right.$ and $\delta^{15} \mathrm{~N}$, respectively) relative to the Pee Dee Belemnite (PDB) for carbon and atmospheric $\mathrm{N}_{2}$ for nitrogen in parts per thousand deviations $(\% \circ)$ using the formula

$\delta(\% o)=1000 \times\left[\frac{R_{\text {sample }}}{R_{\text {standard }}-1}\right]$

Two sulfanilamides (iso-prime internal standards) and two Casein standards were used for every seven unknowns in sequence. Internal laboratory standards indicated measurement errors (SD) of $\pm 0.05 \%$ for $\delta^{13} \mathrm{C}, 0.15 \%$ o for $\delta^{15} \mathrm{~N}$.

\section{Weather data}

We obtained precipitation data from Grisons (108 weather stations; from the Swiss Federal Office of Meteorology and Climatology, MeteoSwiss) as well as from 66 weather stations in adjacent areas within Switzerland, Austria (from Zentralanstalt für Meteorologie und Geodynamik, ZAMG) and Italy (from Agenzia Regionale per la Protezione dell' Ambiente della Lombardia, ARPA Lombardia). We calculated the sum of precipitation of the months April through to August 2013, i.e. the growth period of the year in which we collected plants for isotope analyses. We used these data to analyse geographical differences in precipitation within Grisons (see Statistics, first step).

\section{Statistical analyses}

All statistics were performed in $\mathrm{R}$ (version 3.1.1; $\mathrm{R}$ Core Team, 2014). We conducted linear models (LM) and linear mixed effect models (LMM) using the packages lme4 (Bates, Maechler, \& Bolker, 2011) and lmerTest (Kuznetsova, Brockhoff, \& Christensen, 2014). We performed backwards-stepwise model selection, subsequently removing non-significant variables from the models. $P$ values were obtained from likelihood-ratio tests between models with and without the focal variable.

In the first step, we analysed potential differences in isotopic composition and consequently dietary changes related to the regional precipitation pattern. We therefore (I) analysed the precipitation pattern for the year 2013 in Grisons, running a LM with the sum of precipitation during the growth period (April-August) as dependent variable. As explanatory variables, we included latitude and longitude of the weather station as well as the two-way interaction term (latitude*longitude).

We then (II) took plant samples from all locations into account, and studied the effects of latitude, longitude and elevation on plant isotopes. We ran LMMs separately for $\delta^{15} \mathrm{~N}$ and $\delta^{13} \mathrm{C}$ as dependent variables. As elevation was significantly correlated with latitude and longitude (Pearson's $R=-0.16$ and $0.43, P=0.026$ and $<0.001$, respectively), we conducted models separately for geographic location and elevation to avoid collinearity. The first set of models therefore contained latitude, longitude and the interaction term (latitude*longitude) as explanatory covariates and plant species as random effect. The second set of models contained only elevation as explanatory variable and plant species as random effect.

For the two more intensively sampled locations of Lukmanierpass and Ofenpass, we also tested whether isotope values differed among plant species. We therefore conducted LMMs with plant species as fixed effect and the study site as random effect.

Finally (III), we investigated variation of rock ptarmigan (all data from 2009) and black grouse (all data from 2005) isotope data with latitude and longitude. Again, we ran LMMs separately for $\delta^{15} \mathrm{~N}$ and $\delta^{13} \mathrm{C}$. The starting global model contained species (as fixed factor) and both latitude and longitude (each as covariates) and all possible interaction terms up to the three-way interaction between species, latitude and longitude (as explanatory variables), as well as sex and age (as independent random variables).

In addition to these regional effects, we analysed in a second step potential intra-specific differences in both rock ptarmigan and black grouse. For rock ptarmigan, we used a separate dataset which contained data from the years 2008 to 2012 shot within the range of the municipality of Pontresina. We used this dataset to investigate sex, age and year differences. LMs therefore contained sex, age and year (each as fixed factor) and all possible two- and three-way interactions. For black grouse, we exclusively used the data from 2005 from across Grisons.

Finally, in the third and last step, we analysed potential species differences between rock ptarmigan and black grouse, using a LM with species as the only explanatory factor, applied to the dataset of feather isotope data sampled across Grisons in the years 2005 (adult black grouse) and 2009 (adult rock ptarmigan).

\section{Results}

\section{Geographical effects along a precipitation gradient}

Within Grisons, precipitation during the growth season 2013 (April-August) showed a significant interaction between latitude and longitude (LMM: $F_{1}=12.12$, $P<0.001)$. Tested separately, precipitation decreased with latitude (LMM: $F_{1}=9.90, P=0.002$ ) and longitude (LMM: $\left.F_{1}=90.04, P<0.001\right)$, thus the southern and western parts of the canton received more precipitation than the northern and eastern parts, coinciding with the annual pattern of precipitation (Fig. 1).

Within the same geographical range, plant $\delta^{13} \mathrm{C}$ increased significantly with elevation (LMM: $F_{1}=28.65, P<0.001$ ) (Fig. 2) and with longitude, i.e. from west to east (LMM: 


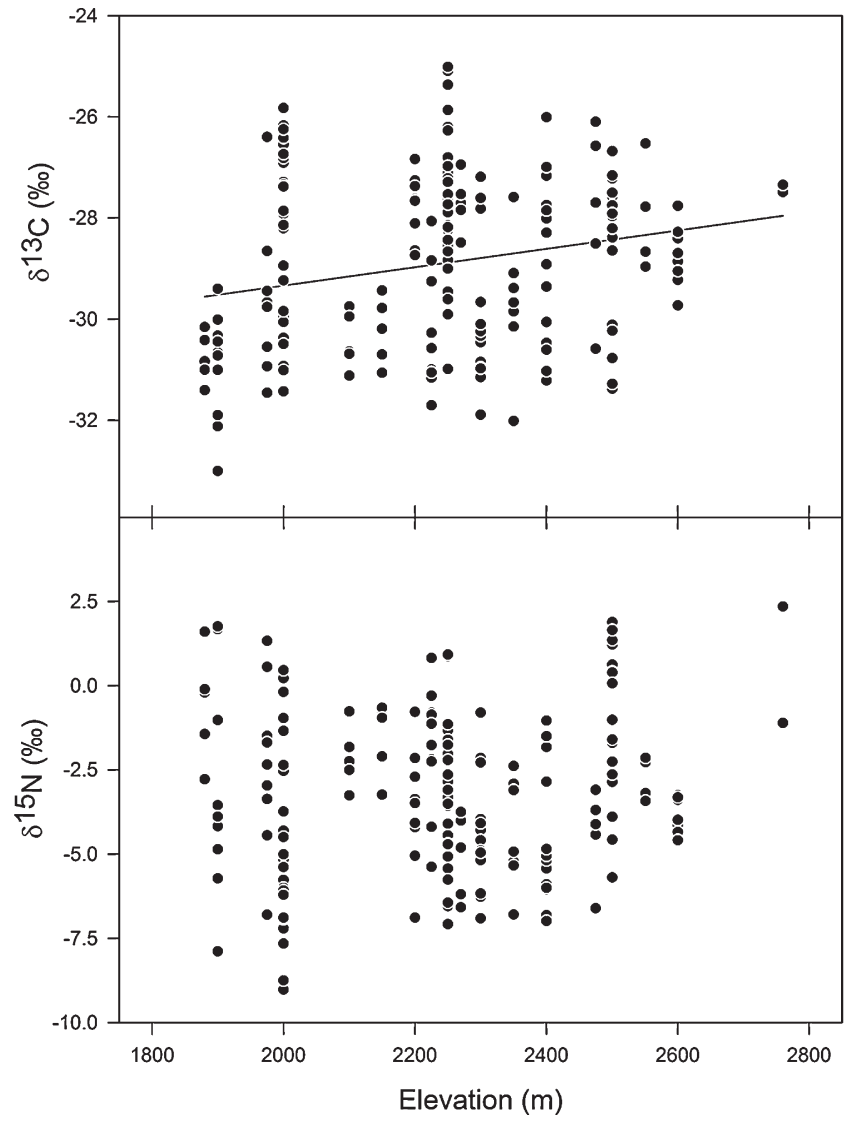

Fig. 2. Effects of elevation on $\delta^{13} \mathrm{C}$ and $\delta^{15} \mathrm{~N}$ of plants. Regression lines are shown for significant effects only.

$\left.F_{1}=23.98, P<0.001\right)$, while there was no significant effect of latitude (LMM: $F_{1}=3.19, P=0.090$ ) (Fig. 3). Plant $\delta^{15} \mathrm{~N}$ values were not significantly affected by elevation (LMM: $F_{1}=0.07, P=0.800$ ) (Fig. 2), latitude (LMM: $F_{1}=2.09$, $P=0.090)$ or longitude (LMM: $\left.F_{1}=0.38, P=0.536\right)($ Fig. 4$)$.

Focussing on the variation among plant species, we found a significant species effect on both $\delta^{13} \mathrm{C}$ and $\delta^{15} \mathrm{~N}$ (LMM: $F_{10}=11.76, P<0.001$ and $F_{10}=2.36, P=0.006$ for $\delta^{13} \mathrm{C}$ and $\delta^{15} \mathrm{~N}$, respectively) at the two intensively sampled locations of Lukmanierpass and Ofenpass (Table A1). Species differences in $\delta^{13} \mathrm{C}$ and $\delta^{15} \mathrm{~N}$ were also present within the family Ericacea (LMM: $F_{7}=13.04$ and 2.07, $P<0.001$ and 0.028, respectively), and differences for $\delta^{13} \mathrm{C}$ remained significant even within the same genus: Mountain cranberry, $V$. vitisidaea, and bilberry, V. myrtillus, sampled at the same study plot (i.e. same geographic location and elevation) differed significantly in their $\delta^{13} \mathrm{C}$ values (LMM: $F_{1}=20.80, P=0.002$ ), but not in their $\delta^{15} \mathrm{~N}$ values (LMM: $F_{1}=0.99, P=0.348$ ).

Analysing rock ptarmigan and black grouse data from across Grisons, we obtained a significant three-way interaction term between species, latitude and longitude for both $\delta^{13} \mathrm{C}$ (LMM: $\left.F_{1}=3.77, P=0.024\right)$ and $\delta^{15} \mathrm{~N}$ values (LMM: $\left.F_{1}=4.35, P=0.018\right)$. We therefore continued with separate analyses for both species.
In rock ptarmigan, feather $\delta^{13} \mathrm{C}$ was independent of latitude (LMM: $F_{1}=0.52, P=0.444$ ) and longitude (LMM: $F_{1}=0.122, P=0.717$; Fig. 3). Feather $\delta^{15} \mathrm{~N}$ was independent of latitude (LMM: $\left.F_{1}=0.08, P=0.906\right)$ but increased with longitude (LMM: $F_{1}=6.11, P=0.013$; Fig. 4).

In black grouse, the interaction term of latitude and longitude had a significant effect on feather $\delta^{13} \mathrm{C}\left(\mathrm{LMM}: F_{1}=7.69\right.$, $P=0.005)$. Analysed in separate models, $\delta^{13} \mathrm{C}$ increased with longitude (LMM: $\left.F_{1}=6.99, P=0.009\right)$ but was not affected by latitude (LMM: $F_{1}=0.65, P=0.412$; Fig. 3 ). Feather $\delta^{15} \mathrm{~N}$ was independent of latitude (LMM: $\left.F_{1}=1.33, P=0.243\right)$ and longitude (LMM: $F_{1}=0.12, P=0.729$; Fig. 4).

\section{Intra-specific differences in rock ptarmigan and black grouse}

We tested intra-specific differences in rock ptarmigan with a 4-year dataset from the municipality of Pontresina and found that feather $\delta^{13} \mathrm{C}$ values were marginally lower in males than females (LM: $F_{1}=4.44, P=0.039$; Fig. A1). Furthermore, the interaction between year and age (LM: $F_{1}=2.59$, $P=0.045$; Fig. A2) was significant. Albeit significant, the overall differences were rather weak (Figs. A1 and A2). Rock ptarmigan feather $\delta^{15} \mathrm{~N}$ values were not affected by either year, sex or age or any interaction term (LM: all $F_{1} \leq 1.69$, all $P \geq 0.164$ ).

In black grouse sampled across Grisons, feather $\delta^{13} \mathrm{C}$ and $\delta^{15} \mathrm{~N}$ values did not differ between adult and immature males (LM: $F_{1}=0.07$ and $0.01, P=0.798$ and 0.986 for $\delta^{13} \mathrm{C}$ and $\delta^{15} \mathrm{~N}$, respectively).

\section{Species differences between rock ptarmigan and black grouse}

Overall, adult rock ptarmigan had significantly higher $\delta^{13} \mathrm{C}$ values (LM: $\left.F_{1}=77.36, P<0.001\right)$ and significantly lower $\delta^{15} \mathrm{~N}$ values (LM: $F_{1}=118.62, P<0.001$ ) than adult black grouse, with isotopic values of both species showing no overlap (Fig. 5).

\section{Discussion}

\section{Effect of latitude and longitude along the precipitation gradient}

Grisons shows a distinct precipitation gradient, with decreasing spring and summer rainfalls from west to east. In agreement with our expectation, plant $\delta^{13} \mathrm{C}$ increased with longitude, but not latitude, and no effect of either latitude or longitude was found for plant $\delta^{15} \mathrm{~N}$. The same pattern was found for black grouse feathers, suggesting that the dietary composition of black grouse did not change along the precipitation gradient with longitude within the study area. 


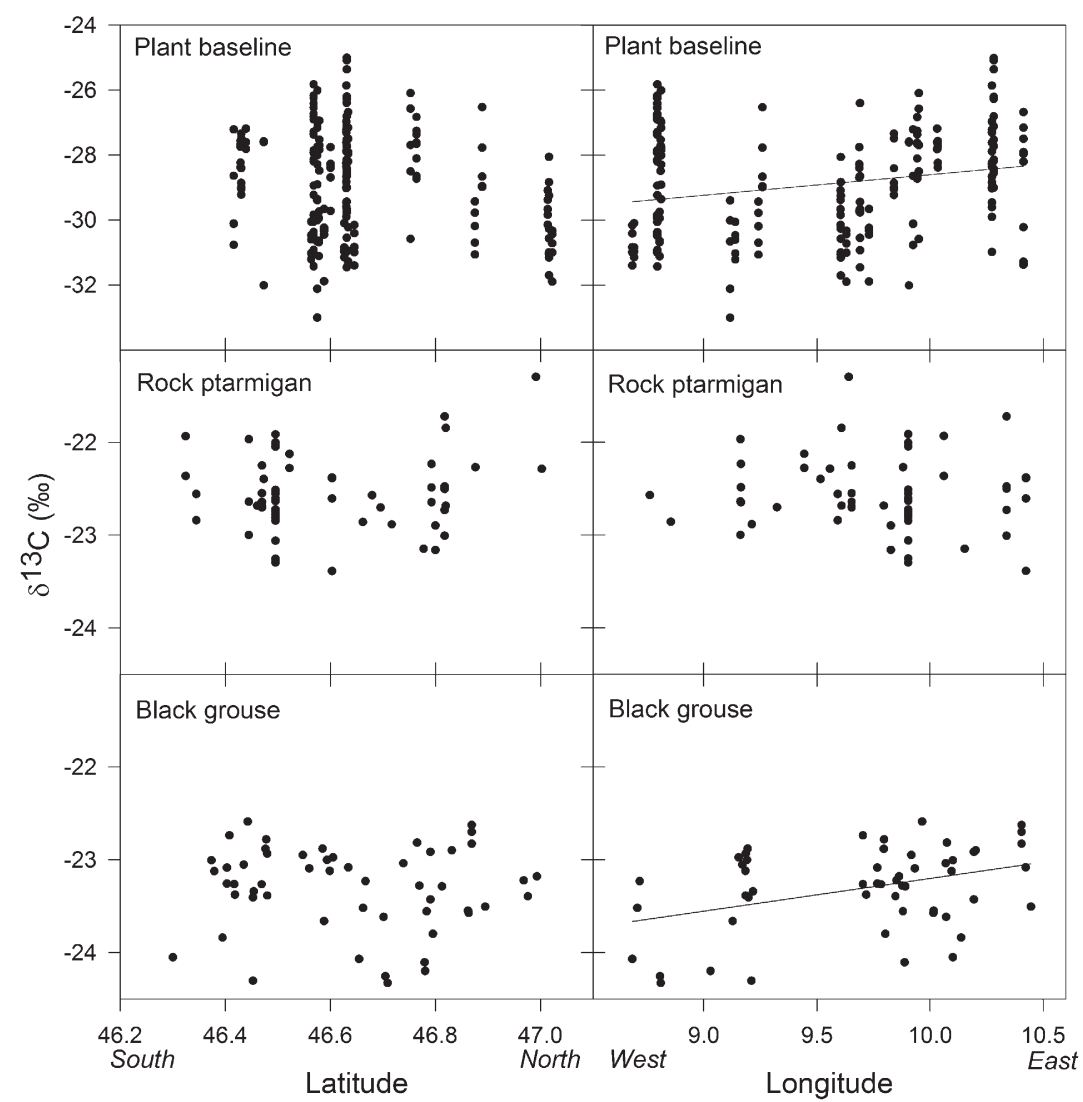

Fig. 3. Effects of latitude and longitude on $\delta^{13} \mathrm{C}$ of plants, rock ptarmigan and black grouse feathers. Note that the scaling for $\delta^{13} \mathrm{C}$ differs between the plants and the two grouse species. Regression lines are shown for significant effects only.

In contrast, in rock ptarmigan, we found a different effect: While $\delta^{13} \mathrm{C}$ in feathers did not differ with either latitude or longitude, $\delta^{15} \mathrm{~N}$ increased with longitude. The latter might suggest that the proportion of insects in the rock ptarmigan diet increased from west to east, and therefore along the precipitation gradient. Albeit significant, the effect itself was rather small and might on its own be biologically hardly meaningful. In addition, however, the longitudinal effect of plant $\delta^{13} \mathrm{C}$ was not reflected in rock ptarmigan feather isotopes. Considering that rock ptarmigan diet appears to be based even more on plants than that of black grouse (for which the effect was visible), this is surprising. Potentially, these combined effects in $\delta^{13} \mathrm{C}$ and $\delta^{15} \mathrm{~N}$ therefore do suggest a change in dietary composition and/or food sources of rock ptarmigan over the longitudinal precipitation gradient.

\section{Intra-specific variation in isotopes}

Against our expectations, we found no age-dependent differences in dietary composition in either rock ptarmigan or black grouse. Although invertebrate diet is expected to be common in immature individuals, we found no differences in $\delta^{15} \mathrm{~N}$ (which would have indicated a more invertebrate-rich diet in immatures). While young black grouse in Norway and northern England took substantially more insect prey compared to adults (Starling-Westerberg 2001; Wegge \& Kastdalen 2008), we are not aware of any studies from the European Alps that compared the diet between adults and juveniles. In rock ptarmigan, earlier studies from Greenland and the Alps suggested that dietary segregation with age might be less strong compared to black grouse (Lieser et al. 1997 and literature therein). Furthermore, potential differences in the diet might decrease with age of the juveniles, and may not be present any more during formation of secondary wing feathers (which our isotope analyses were based upon).

\section{Inter-specific differences in the isotopic values and diet}

Black grouse had significantly lower $\delta^{13} \mathrm{C}$ and higher $\delta^{15} \mathrm{~N}$ levels than rock ptarmigan, with no overlap of isotopic values. As rock ptarmigan are distributed at higher altitudes than black grouse, and based on our expectations (and findings) that plant $\delta^{13} \mathrm{C}$ increases with elevation, we anticipated to find the here-observed species-segregation in $\delta^{13} \mathrm{C}$ independent of dietary preferences of both species. Assuming a similar diet in both species, we expected to find similar $\delta^{15} \mathrm{~N}$ values in both species. Instead, black grouse feathers had on average $2.5 \%$ higher $\delta^{15} \mathrm{~N}$ values than rock ptarmigan feathers. This 


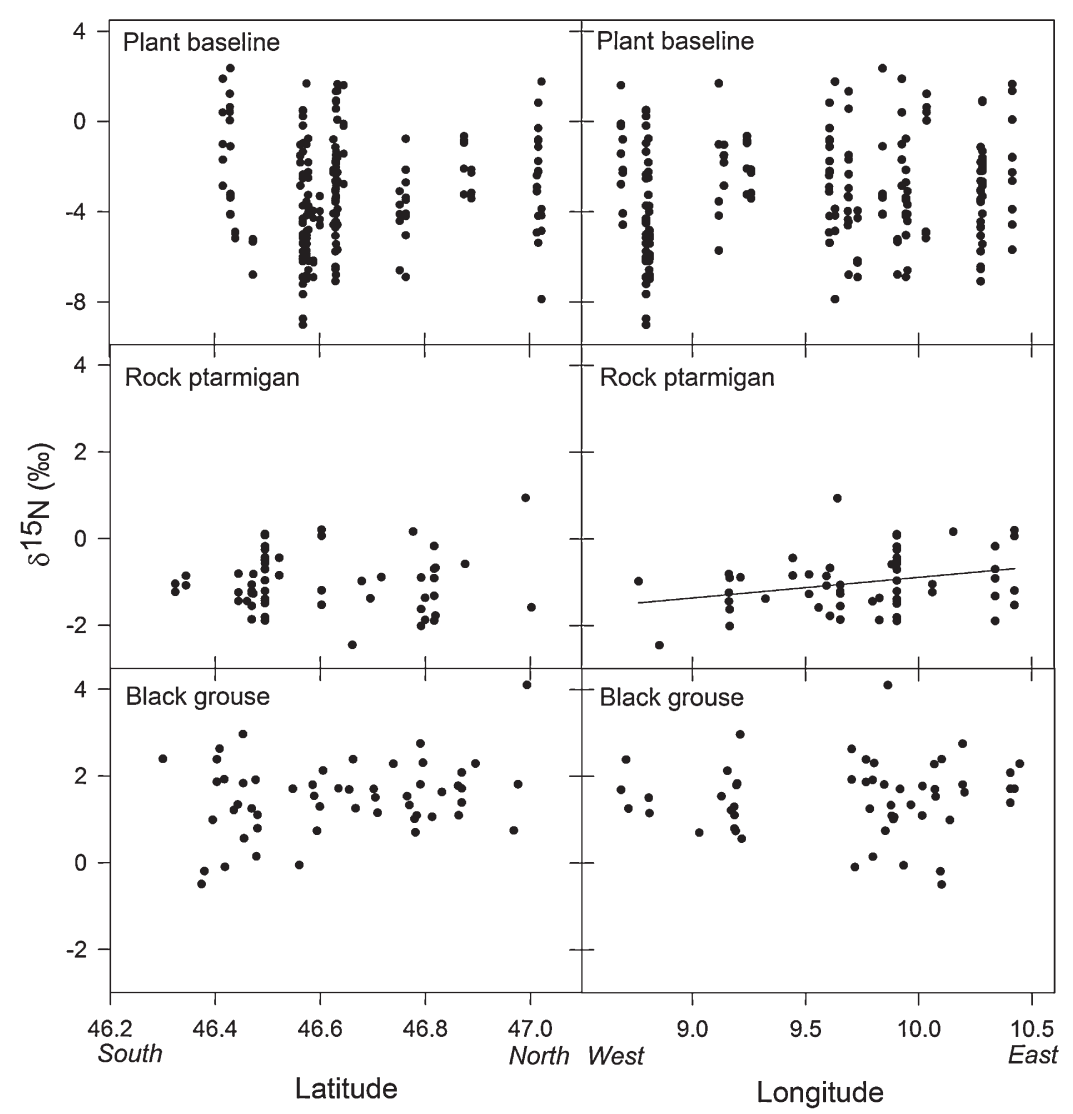

Fig. 4. Effects of latitude and longitude on $\delta^{15} \mathrm{~N}$ of plants, rock ptarmigan and black grouse feathers. Note that the scaling for $\delta^{15} \mathrm{~N}$ differs between the plants and the two grouse species. Regression lines are shown for significant effects only.

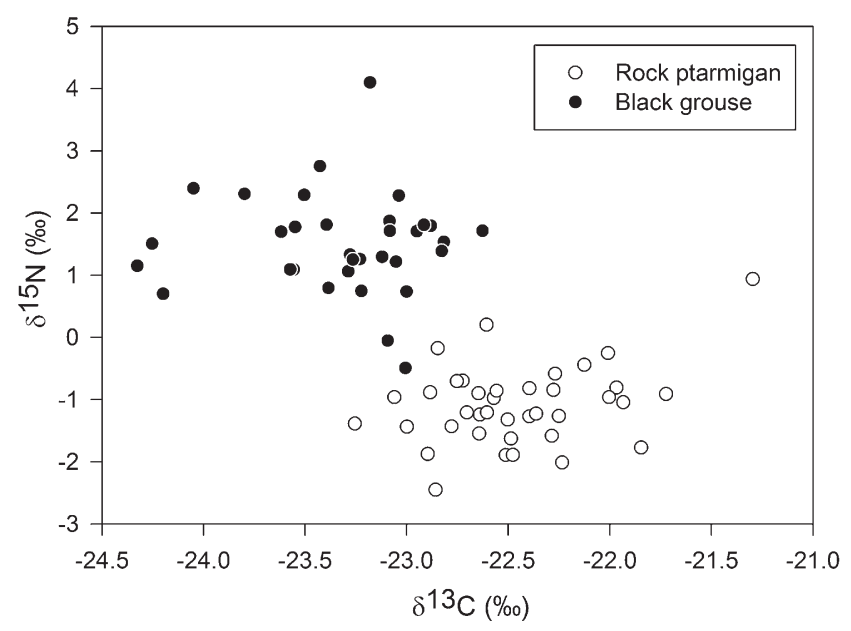

Fig. 5. Stable nitrogen and carbon isotope ratios (\%o) of adult rock ptarmigan and black grouse. Each point represents one individual adult bird from Grisons. $N=38$ rock ptarmigan and 33 black grouse, respectively.

difference cannot be ascribed to an effect of altitude, as plant isotopes did not differ in $\delta^{15} \mathrm{~N}$ with elevation. Theoretically, the species differences in $\delta^{15} \mathrm{~N}$ could be explained by black grouse feeding consistently on plant species with higher $\delta^{15} \mathrm{~N}$ values compared to rock ptarmigan. However, variability in $\delta^{15} \mathrm{~N}$ was also large within plant species, even within the same study plots, i.e. within a range of a few metres (see standard deviations shown in Table A1). It therefore appears unlikely that black grouse consistently selected for plant specimen with high $\delta^{15} \mathrm{~N}$, whereas rock ptarmigan did the opposite. A more likely explanation for both the higher $\delta^{15} \mathrm{~N}$ values in black grouse and the larger intra-specific variation in $\delta^{15} \mathrm{~N}$ in this species would be that black grouse feed on a higher proportion of invertebrates compared to rock ptarmigan. Along the food chain, $\delta^{15} \mathrm{~N}$ increases with each trophic step (DeNiro \& Epstein 1981; Minagawa \& Wada 1984). This trophic fractionation ranges between approximately $2 \%$ and $5 \%$ (Post 2002). The difference in $\delta^{15} \mathrm{~N}$ between black grouse and rock ptarmigan therefore represented a difference by about half to one trophic level, suggesting that invertebrates make up a considerable amount of diet in black grouse. In contrast, diet in rock ptarmigan can be expected to be based primarily on plants due to the rather small difference (on average $2.22 \%$ ) in $\delta^{15} \mathrm{~N}$ between analysed plant material and rock ptarmigan feathers.

The literature so far ascribed a similar, mainly plantbased diet to adults of both of our study species (Glutz von Blotzheim et al. 1973; Lieser et al. 1997; Bertermann et al. 1998; Starling-Westerberg 2001; Beeston et al. 2005). While 
we are unable to identify with certainty whether a differential plant diet or the proportion of invertebrates cause the differences in $\delta^{15} \mathrm{~N}$, our data clearly suggest a dietary segregation between black grouse and rock ptarmigan, which has not been described previously.

\section{Potential caveats of this study}

We conducted stable isotope analyses only for a limited number of plant specimen and plant species, not covering the entire food web of rock ptarmigan and black grouse. In particular, we did not sample any invertebrates, which - with hindsight - could have helped with the interpretation of our results. Variation in both $\delta^{13} \mathrm{C}$ and $\delta^{15} \mathrm{~N}$ within and between plant species was large, also within species and within study plots (see Table A1), and variation would likely be even larger under inclusion of more plant specimen. Due to this strong variation and the high overlap of isotope values among plant species, and further lack of knowledge about the fractionation factors between isotopic ratios in the birds' food and their feathers, we decided against running stable isotope mixing models as results would come with a large level of uncertainty. Consequently, we were, however, not able to estimate specific dietary components in the diet of rock ptarmigan and black grouse.

Our sampling design was furthermore suboptimal in that plants, rock ptarmigan and black grouse feathers had to be sampled in three different years. We therefore cannot rule out entirely that long-term year-effects may have biased our results. However, we would like to emphasise that (1) there were no substantial and biologically meaningful yeardifferences in either $\delta^{13} \mathrm{C}$ or $\delta^{15} \mathrm{~N}$ in feathers from rock ptarmigan within the municipality of Pontresina; and (2) according to MeteoSwiss the precipitation gradient with longitude in Grisons was present across the entire period for which samples from either birds or plants were obtained. We therefore assume that despite the suboptimal sampling design, our finding of dietary segregation between rock ptarmigan and black grouse is robust.

\section{Conclusions/implications of this study}

Alpine wildlife is severely affected by anthropogenic influences, from land use patterns to global climate change that will affect temperature and precipitation patterns in the Alps. One aim of this study was therefore to investigate the dietary changes along a precipitation gradient within the central European Alps in both rock ptarmigan and black grouse. Overall, our data suggested a potential effect of precipitation on the diet of rock ptarmigan and no effect on black grouse. The more significant and slightly unexpected results of this study were, however, the dietary segregation of rock ptarmigan and black grouse.

\section{Acknowledgements}

Saskia Rehse, Corinna Waider, Claudia Greis and Wolfgang Kornberger helped with stable isotope analyses and Marc Mischke with generating the GIS plots. Thanks to Dan Suri for helpful discussions about precipitation data and English proofreading. We thank Prof. K.O. Rothhaupt and the staff at the Limnological Institute at the University of Konstanz for logistical support. This study was funded by the Otto Wolff Stiftung. ND was supported by the FWO-Flanders during writing of this manuscript (grant numbers $1265414 \mathrm{~N}$ and 12Q6915N).

\section{Appendix A. Supplementary data}

Supplementary data associated with this article can be found, in the online version, at http://dx.doi.org/10.1016/ j.baae.2016.04.007.

\section{References}

Bates, D., Maechler, M., \& Bolker, B. (2011). Ime4: Linear mixedeffects models using S4 classes, R package version 0.999375-42. http://CRAN.R-project.org/package=lme4

Bearhop, S., Waldron, S., Votier, S. C., \& Furness, R. W. (2002). Factors that influence assimilation rates and fractionation of nitrogen and carbon stable isotopes in avian blood and feathers. Physiological and Biochemical Zoology, 75, 451-458.

Beeston, R., Baines, D., \& Richardson, M. (2005). Seasonal and between-sex differences in the diet of black grouse Tetrao tetrix: Capsule dietary differences between sexes and seasons reflected diversity in plant availability and habitat preferences. Bird Study, 52, 276-281.

Begert, M., Schlegel, T., \& Kirchhofer, W. (2005). Homogeneous temperature and precipitation series of Switzerland from 1864 to 2000. International Journal of Climatology, 25, 65-80.

Begon, M., Townsend, C. R., \& Harper, J. L. (2006). Ecology - From individuals to ecosystems (4th ed.). Malden, MA: Blackwell Publishing.

Bertermann, C., Weber-Sparenberg, C., Pechura, A., Renard, A.-I., \& Bergmann, H.-H. (1998). Zur Ernährung von Alpenschneehühnern Lagopus mutus helveticus im Sommer. Egretta, 41, $15-26$.

Braunisch, V., Patthey, P., \& Arlettaz, R. (2010). Spatially explicit modeling of conflict zones between wildlife and snow sports: Prioritizing areas for winter refuges. Ecological Applications, 21, 955-967.

Caut, S., Angulo, E., \& Courchamp, F. (2009). Variation in discrimination factors $\left(\Delta^{15} \mathrm{~N}\right.$ and $\left.\Delta^{13} \mathrm{C}\right)$ : The effect of diet isotopic values and applications for diet reconstruction. Journal of Applied Ecology, 46, 443-453.

DeNiro, M. J., \& Epstein, S. (1981). Influence of diet on the distribution of nitrogen isotopes in animals. Geochimica et Cosmochimica Acta, 45, 341-351. 
Dirnböck, T., Dullinger, S., \& Grabherr, G. (2003). A regional impact assessment of climate and land-use change on alpine vegetation. Journal of Biogeography, 30, 401-417.

Dirnböck, T., Essl, F., \& Rabitsch, W. (2011). Disproportional risk for habitat loss of high-altitude endemic species under climate change. Global Change Biology, 17, 990-996.

Dullinger, S., Dirnböck, T., \& Grabherr, G. (2004). Modelling climate change-driven treeline shifts: Relative effects of temperature increase, dispersal and invasibility. Journal of Ecology, 92, 241-252.

Engler, R., Randin, C. F., Thuiller, W., Dullinger, S., Zimmermann, N. E., Araúja, M. B., et al. (2011). 21st century climate change threatens mountain flora unequally across Europe. Global Change Biology, 17, 2330-2341.

Favaron, M., Scherini, G., Preatoni, D., Tosi, G., \& Wauters, L. (2006). Spacing behaviour and habitat use of rock ptarmigan (Lagopus mutus) at low density in the Italian Alps. Journal of Ornithology, 147, 618-628.

Ferrio, J. P., \& Voltas, J. (2005). Carbon and oxygen isotope ratios in wood constituents of Pinus halepensis as indicators of precipitation, temperature and vapour pressure deficit. Tellus B, 57, 164-173.

Fette, M., Weber, C., Peter, A., \& Wehrli, B. (2007). Hydropower production and river rehabilitation: A case study on an alpine river. Environmental Modeling \& Assessment, 12, 257-267.

Frei, C., \& Schär, C. (1998). A precipitation climatology of the Alps from high-resolution rain-gauge observations. International Journal of Climatology, 18, 873-900.

Frey, W., \& Lösch, R. (2004). Lehrbuch der Geobotanik. Plfanze und Vegetation in Raum und Zeit. Munich, Germany: Elsevier.

Fry, B. (2006). Stable isotope ecology. New York: Springer.

Furrer, R., Schaub, M., Bossert, A., Isler, R., Jenny, H., Jonas, T., et al. (2016). Variable decline of alpine rock ptarmigan (Lagopus muta helvetica) in Switzerland between regions and sites. Journal of Ornithology, http://dx.doi.org/10.1007/s10336-016-1324-8

Glutz von Blotzheim, U. N., Bauer, K. M., \& Bezzel, E. (1973). Handbuch der Vögel Mitteleuropas. Band 5. Galliformes und Gruiformes. Frankfurt am Main, Germany: Akademische Verlagsgesellschaft.

Gobiet, A., Kotlarski, S., Beniston, M., Heinrich, G., Rajczak, J., \& Stoffel, M. (2014). 21st century climate change in the European Alps-A review. Science of the Total Environment, 493, $1138-1151$.

Keller, V., Gerber, A., Schmid, H., Volet, B., \& Zbinden, N. (2010). Rote Liste Brutvögel. Stand: Gefährdete Arten der Schweiz.

Körner, C., Farquhar, G. D., \& Roksandic, Z. (1988). A global survey of carbon isotope discrimination in plants from high altitude. Oecologia, 74, 623-632.

Kuznetsova, A., Brockhoff, B., \& Christensen, H. B. (2014). lmerTest: Tests for random and fixed effects for linear mixed effect models (lmer objects of lme4 package). R package version 2.0-11. http://CRAN.R-project.org/package=lmerTest

Lieser, M., Zakrzewski, M., \& Sittler, B. (1997). Summer ecology of ptarmigan Lagopus mutus on Traill Island, NE Greenland. Der Ornithologische Beobachter, 94, 225-232.

Meusburger, K., \& Alewell, C. (2008). Impacts of anthropogenic and environmental factors on the occurrence of shallow landslides in an alpine catchment (Urseren Valley, Switzerland). Natural Hazards and Earth System Science, 8, 509-520.
Minagawa, M., \& Wada, E. (1984). Stepwise enrichment of ${ }^{15} \mathrm{~N}$ along food chains: Further evidence and the relation between $\delta^{15} \mathrm{~N}$ and animal age. Geochimica et Cosmochimica Acta, 48, $1135-1140$.

Negro, M., Isaia, M., Palestrini, C., Schoenhofer, A., \& Rolando, A. (2010). The impact of high-altitude ski pistes on grounddwelling arthropods in the Alps. Biodiversity and Conservation, 19, 1853-1870.

Ohlemüller, R., Anderson, B. J., Araújo, M. B., Butchart, S. H. M., Kudrna, O., Ridgely, R. S., et al. (2008). The coincidence of climatic and species rarity: High risk to small-range species from climate change. Biology Letters, 4, 568-572.

Parolo, G., \& Rossi, G. (2008). Upward migration of vascular plants following a climate warming trend in the Alps. Basic and Applied Ecology, 9, 100-107.

Paschetta, M., La Morgia, V., Masante, D., Negro, M., Rolando, A., \& Isaia, M. (2013). Grazing history influences biodiversity: A case study on ground-dwelling arachnids (Arachnida: Araneae, Opiliones) in the Natural Park of Alpi Marittime (NW Italy). Journal of Insect Conservation, 17, 339-356.

Patthey, P., Signorell, N., Rotelli, L., \& Arlettaz, R. (2012). Vegetation structural and compositional heterogeneity as a key feature in Alpine black grouse microhabitat selection: Conservation management implications. European Journal of Wildlife Research, 58, 59-70.

Pernollet, C. A., Korner-Nievergelt, F., \& Jenni, L. (2015). Regional changes in the elevational distribution of the Alpine rock ptarmigan Lagopus muta helvetica in Switzerland. Ibis, 157.

Peronace, V., Cecere, J. G., Gustin, M., \& Rondinini, C. (2012). The 2011 red list of Italian breeding birds. Avocetta, 36, $11-58$.

Post, D. M. (2002). Using stable isotopes to estimate trophic position: Models, methods, and assumptions. Ecology, 83.

R Core Team. (2014). R: A language and environment for statistical computing. Vienna, Austria: R Foundation for Statistical Computing. http://www.R-project.org/

Revermann, R., Schmid, H., Zbinden, N., Spaar, R., \& Schroder, B. (2012). Habitat at the mountain tops: How long can rock ptarmigan (Lagopus muta helvetica) survive rapid climate change in the Swiss Alps? A multi-scale approach. Journal of Ornithology, 153, 891-905.

Schmid, H., Luder, R., Naef-Daenzer, B., Graf, R., \& Zbinden, N. (1998). Schweizer Brutvogelatlas. Verbreitung der Brutvögel in der Schweiz und im Fürstentum Liechtenstein 1993-1996. Sempach, Switzerland: Schweizerische Vogelwarte.

Schweiger, A. K., Nopp-Mayr, U., \& Zohmann, M. (2012). Small-scale habitat use of black grouse (Tetrao tetrix L.) and rock ptarmigan (Lagopus muta helvetica Thienemann) in the Austrian Alps. European Journal of Wildlife Research, 58, $35-45$.

Starling-Westerberg, A. (2001). The habitat use and diet of black grouse Tetrao tetrix in the Pennine hills of northern England. Bird Study, 48, 76-89.

Stewart, G., Turnbull, M., Schmidt, S., \& Erskine, P. (1995). ${ }^{13}$ C natural abundance in plant communities along a rainfall gradient: A biological integrator of water availability. Functional Plant Biology, 22, 51-55.

Storch, I. (2007). Conservation status of grouse worldwide: An update. Wildlife Biology, 13, 5-12. 
Truffer, B., Markard, J., Bratrich, C., \& Wehrli, B. (2001). Green electricity from Alpine hydropower plants. Mountain Research and Development, 21, 19-24.

Van de Water, P. K., Leavitt, S. W., \& Betancourt, J. L. (2002). Leaf $\delta^{13} \mathrm{C}$ variability with elevation, slope aspect, and precipitation in the southwest United States. Oecologia, 132, 332-343.

Wegge, P., \& Kastdalen, L. (2008). Habitat and diet of young grouse broods: Resource partitioning between capercaillie (Tetrao urogallus) and black grouse (Tetrao tetrix) in boreal forests. Journal of Ornithology, 149, 237-244.

Zimmermann, N. E., Gebetsroither, E., Züger, J., Schmatz, D., \& Psomas, A. (2013). Future climate of the European
Alps. In G. A. Cerbu, M. Hannewinkel, G. Gerosa, \& R. Jandl (Eds.), Management strategies to adapt alpine space forests to climate change risks (pp. 27-36). Rijeka, Croatia: InTech.

Zohmann, M., \& Wöss, M. (2008). Spring density and summer habitat use of alpine rock ptarmigan Lagopus muta helvetica in the southeastern Alps. European Journal of Wildlife Research, 54, 379-383.

Zurell, D., Grimm, V., Rossmanith, E., Zbinden, N., Zimmermann, N. E., \& Schröder, B. (2012). Uncertainty in predictions of range dynamics: Black grouse climbing the Swiss Alps. Ecography, $35,590-603$. 